\section{Yield Performance of Cowpea Plant Introductions Grown in Calcareous Soils}

\author{
Ricardo Goenaga ${ }^{1,3}$, Tomas Ayala $^{2}$, and Adolfo Quiles ${ }^{1}$
}

AdDitional INDEX wORDs. seed protein, Vigna unguiculata, soil alkalinity

Summary. Cowpea or southernpea (Vigna unguiculata) is an important legume crop used as a feed for livestock, as a green vegetable and for consumption of its dry beans, which provide $22 \%$ to $25 \%$ protein. The crop is very sensitive to alkaline soil conditions. When grown at a soil $\mathrm{pH}$ of 7.5 or higher, cowpea develops severe leaf chlorosis caused by deficiencies of iron, zinc, and manganese resulting in stunted plant growth and yield reduction. We evaluated in replicated field experiments at $S t$ Croix, U.S. Virgin Islands, and Miami, FL, four PIs and one commercial cultivar, some of which have shown some tolerance to alkaline soils in unreplicated, seed regeneration plots of the U.S. cowpea collection. At both locations, PI 582702 had significantly higher seed protein concentration than the other PIs, averaging $28 \%$. Alkaline soil conditions at St. Croix were severe resulting in average yield of PIs at this location being significantly lower and 69\% less than that in Florida. Nevertheless, some PIs performed well at both locations. For example, PI 582605 had significantly higher yield in Florida, whereas in St. Croix, PIs 582605, 582674, and $\mathbf{5 8 2 7 0 2}$ were the highest yielders. These PIs may serve as an alternative to growers or home gardeners wishing to establish a legume crop in areas where agricultural production is severely restricted by high soil alkalinity.

$\mathrm{C}$ owpea is an important grain legume crop used as a feed for livestock and as a green vegetable, and its dry beans provide $22 \%$ to $25 \%$ protein (Goenaga et al., 2008; Murillo-Amador et al., 2006). Because of its versatility, high nutrition, and self-pollinating nature, cowpea has been advocated as a candidate crop for space agriculture (Nelson et al., 2008). World production of cowpea was 5.63 million tons in 2010 with $95 \%$ of total production originating in African nations (Food and Agriculture Organization of the United Nations, 2012).

Calcareous soils, where cowpea is often grown, cover more than $30 \%$ of the earth's soil surface (George et al., 2012). When grown at $\mathrm{pH}>7.5$, cowpea develops severe leaf chlorosis

The authors thank Reinardo Vasquez and Luis Parrilla for their excellent field assistance.

Mention of trade names or commercial products in this publication is solely for the purpose of providing specific information and does not imply recommendation or endorsement of the U.S. Department of Agriculture.

${ }^{1}$ Agricultural Research Service, U.S. Department of Agriculture, Tropical Agriculture Research Station, 2200 P.A. Campos Avenue, Suite 201, Mayaguez, PR 00680

${ }^{2}$ Agricultural Research Service, U.S. Department of Agriculture, Subtropical Horticulture Research Station, 13601 Old Cutler Road, Miami, FL 33158

${ }^{3}$ Corresponding author. E-mail: Ricardo.Goenaga@ ars.usda.gov. caused by deficiencies of iron $(\mathrm{Fe})$, zinc $(\mathrm{Zn})$, and often manganese $(\mathrm{Mn})$. To our knowledge, there are no commercial cowpea cultivars possessing alkaline soil tolerance, but evidence of genotypic differences has been observed (R. Goenaga, unpublished data). For over 10 years, seeds of photoperiodsensitive accessions in the U.S. Department of Agriculture (USDA) cowpea collection has been regenerated at the USDA-Agricultural Research Service (ARS) facilities in St. Croix, U.S. Virgin Islands (Gillaspie et al., 1999), in part because incidence of pests and diseases of cowpea at this site are minimal because of the absence of large plantings of this or related crops. Genetic diversity for tolerance to alkaline soil conditions, such as those encountered at St. Croix, has been observed by the authors during these regeneration cycles in field plots with $\mathrm{pH}>8.0$. Tolerance is defined in this study as the ability of a PI to produce a good crop (seed yield over $1000 \mathrm{~kg} \cdot \mathrm{ha}^{-1}$ ) when field grown at a $\mathrm{pH}>7.5$.

The present study was conducted with the objective of determining yield potential of selected cowpea PIs that have shown alkaline soil tolerance in unreplicated seed regeneration plots as an effort to identify PIs that could be used in areas where agricultural production may be limited by high soil alkalinity of calcareous soils.

\section{Materials and methods}

This study was conducted at the USDA-ARS, Germplasm Introduction and Research Unit in St. Croix, U.S. Virgin Islands (coarse-loamy, carbonatic, isohyperthermic Typic Calciustolls) and at the USDA-ARS, Subtropical Horticulture Research Station, Miami, FL (Loamy-skeletal, carbonatic, hyperthermic Lithic Udorthents). Soil and climatic characteristics at each site are described in Tables 1 and 2 .

Field experiments in St. Croix were established on 11 Sept. 2008 and 2 July 2009 and in Miami on 9 Sept. 2008 and 2 July 2009. The phenotypic descriptors and origin of the PIs in the experiment are described in Table 3. These PIs had shown some tolerance to alkaline soils in unreplicated, seed regeneration plots of the U.S. cowpea germplasm collection. The tropically adapted commercial cultivar Coronet was used as a commercial control. The experiments were planted in a randomized complete block design with five replications. Because of the prostate growth habit of some PIs, experimental plots consisted of four, $20-\mathrm{ft}$ rows spaced $3.0 \mathrm{ft}$ apart. Seedlings were thinned to an

\begin{tabular}{llll}
\hline $\begin{array}{l}\text { Units } \\
\text { To convert U.S. to SI, } \\
\text { multiply by }\end{array}$ & U.S. unit & SI unit & $\begin{array}{l}\text { To convert SI to U.S., } \\
\text { multiply by }\end{array}$ \\
\hline 1 & $\mathrm{cbar}$ & $\mathrm{kPa}$ & 1 \\
29.5735 & $\mathrm{fl} \mathrm{oz}$ & $\mathrm{mL}$ & 0.0338 \\
0.3048 & $\mathrm{ft}$ & $\mathrm{m}$ & 3.2808 \\
2.54 & inch $(\mathrm{es})$ & $\mathrm{cm}$ & 0.3937 \\
25.4 & inch $(\mathrm{es})$ & $\mathrm{mm}$ & 0.0394 \\
1.1209 & $\mathrm{lb} / \mathrm{acre}$ & $\mathrm{kg} \cdot \mathrm{ha}^{-1}$ & 0.8922 \\
1000 & $\mathrm{mmho} / \mathrm{cm}$ & $\mu \mathrm{\mu S} \cdot \mathrm{cm}^{-1}$ & 0.0010 \\
28.3495 & $\mathrm{oz}$ & $\mathrm{g}$ & 0.0353 \\
1 & $\mathrm{ppm}$ & $\mathrm{mg} \cdot \mathrm{kg}^{-1}$ & 1 \\
0.9072 & ton $(\mathrm{s})$ & ton $(\mathrm{s})$ & 1.1023 \\
$\left({ }^{\circ} \mathrm{F}-32\right) \div 1.8$ & ${ }^{\circ} \mathrm{F}$ & ${ }^{\circ} \mathrm{C}$ & $\left({ }^{\circ} \mathrm{C} \times 1.8\right)+32$
\end{tabular}


Table 1. Average preplant soil characteristics at Miami, FL, and St. Croix, U.S. Virgin Islands, measured to a depth of $20 \mathrm{~cm}$ (7.9 inches) at the experimental sites.

\begin{tabular}{|c|c|c|c|}
\hline \multirow[b]{2}{*}{ Soil characteristic ${ }^{\mathrm{z}}$} & \multicolumn{2}{|c|}{ St. Croix } & \multirow{2}{*}{$\frac{\text { Florida }}{2008-09}$} \\
\hline & 2008 & 2009 & \\
\hline $\mathrm{pH}$ in water & 8.2 & 8.1 & 8.3 \\
\hline $\mathrm{pH}$ in calcium chloride & 7.6 & 7.6 & 7.6 \\
\hline Electrical conductivity $\left(\mu \mathrm{S} \cdot \mathrm{cm}^{-1}\right)$ & 124.2 & 141.0 & 110.6 \\
\hline Ammonium nitrogen $\left(\mathrm{mg} \cdot \mathrm{kg}^{-1}\right)$ & 140 & 104 & 147 \\
\hline Nitrate nitrogen $\left(\mathrm{mg} \cdot \mathrm{kg}^{-1}\right)$ & 60 & 143 & 64 \\
\hline Organic carbon $(\%)$ & 1.35 & 1.40 & 0.95 \\
\hline Phosphorus $\left(\mathrm{mg} \cdot \mathrm{kg}^{-1}\right)$ & 39 & 59 & 79 \\
\hline Potassium $\left(\mathrm{mg} \cdot \mathrm{kg}^{-1}\right)$ & 318 & 743 & 634 \\
\hline Calcium $\left(\mathrm{mg} \cdot \mathrm{kg}^{-1}\right)$ & 4256 & 3407 & 1432 \\
\hline $\operatorname{Magnesium}\left(\mathrm{mg} \cdot \mathrm{kg}^{-1}\right)$ & 206 & 215 & 20 \\
\hline Bicarbonate $(\mathrm{mm})$ & 4.2 & 2.9 & 4.0 \\
\hline Iron $\left(\mathrm{mg} \cdot \mathrm{kg}^{-1}\right)$ & $\mathrm{ND}^{\mathrm{x}}$ & ND & ND \\
\hline Manganese $\left(\mathrm{mg} \cdot \mathrm{kg}^{-1}\right)$ & 0.7 & 2.4 & 1.3 \\
\hline $\operatorname{Zinc}\left(\mathrm{mg} \cdot \mathrm{kg}^{-1}\right)$ & ND & ND & 0.6 \\
\hline
\end{tabular}

${ }^{2} 1 \mathrm{mg} \cdot \mathrm{kg}^{-1}=1 \mathrm{ppm}, 1 \mu \mathrm{S} \cdot \mathrm{cm}^{-1}=0.0010 \mathrm{mmho} / \mathrm{cm}$.

The same plot was used in Florida in 2008 and 2009

${ }^{x} \mathrm{ND}=$ not determined.

Table 2. Total rainfall and average daily maximum and minimum temperatures in Miami, FL, and in St. Croix, U.S. Virgin Islands, during the growth experimental period.

\begin{tabular}{|c|c|c|c|c|}
\hline \multirow[b]{3}{*}{ Site characteristic ${ }^{\mathrm{z}}$} & \multicolumn{4}{|c|}{ Location } \\
\hline & \multicolumn{2}{|c|}{ Florida } & \multicolumn{2}{|c|}{ St. Croix } \\
\hline & 2008 & 2009 & 2008 & 2009 \\
\hline Rainfall (mm) & 39.7 & 59.7 & 46.6 & 20.9 \\
\hline Maximum temperature $\left({ }^{\circ} \mathrm{C}\right)$ & 28.4 & 32.8 & 29.9 & 32.1 \\
\hline Minimum temperature $\left({ }^{\circ} \mathrm{C}\right)$ & 21.1 & 25.6 & 23.4 & 25.8 \\
\hline
\end{tabular}

inrow spacing of $15 \mathrm{~cm}$. Fertilization was provided one month after planting, using a $12 \mathrm{~N}-5.2 \mathrm{P}-10 \mathrm{~K}$ fertilizer at a rate of $422 \mathrm{~kg} \cdot \mathrm{ha}^{-1}$. Plants were drip irrigated at both locations when the soil water tension at a depth of $30 \mathrm{~cm}$ exceeded $\approx 15 \mathrm{kPa}$. Midbloom and maturity were determined as the number of days after planting at which $50 \%$ of plants flowered and the first dry pod appeared, respectively. Pods were harvested by hand as they matured, dried at $38^{\circ} \mathrm{C}, 25 \%$ relative humidity, and shelled. Seed yield was then determined by extrapolating total plot seed weight to a per area basis. Plant height was measured with a ruler at midrow. Pod length was determined by averaging the length of 10 mature pods from each of five plants selected randomly from each plot. Random 100 -seed samples from each replication were weighed to determine seed weight for each PI. Seed nitrogen (N) was determined using the micro-Kjeldahl procedure and multiplied by the factor 6.25 to obtain percent seed protein (Association of Official Analytical Chemists, 2000).

Soil from each block was sampled $\approx 3$ weeks before planting by taking four borings at a depth of 0 to $20 \mathrm{~cm}$ from each of the projected cultivar rows. Samples were air-dried and passed through a 20 mesh screen. Soil $\mathrm{pH}$ in water and $0.01 \mathrm{M}$ calcium chloride (1 soil:2 water) were measured with a glass electrode. Exchangeable cations [potassium $(\mathrm{K})$, magnesium $(\mathrm{Mg})$, calcium (Ca), manganese (Mn)] were extracted with neutral $1 \mathrm{~N}$ ammonium acetate and determined by atomic absorption spectroscopy (Sumner and Miller, 2007). Phosphorus (P) was extracted with $\mathrm{pH} 8.5$ sodium bicarbonate and determined using the ascorbic acid method (Nelson and Sommers, 2007). Organic carbon (C) was determined by the Walkley-Black method
(Nelson and Sommers, 2007). Soil electrical conductivity was determined with a conductivity meter (Orion 3Star; Thermo Scientific, Fort Collins, CO) using $20 \mathrm{~g}$ of soil in $40-\mathrm{mL}$ distilled water. Soil ammonium and nitrate were determined by steam distillation (Mulvaney, 2007). Bicarbonate was determined in a saturated soil paste by titrating with $0.05 \mathrm{~N}$ sulfuric acid standardized with $0.01 \%$ methyl orange indicator (USDA, 1996).

Analysis of variance was carried out using the GLM procedure of SAS (release 9.1 for Windows; SAS Institute, Cary, NC). After significant F tests at $P \leq 0.05$, means separation was performed using the Tukey's Studentized range test.

\section{Results and discussion}

Location and PIs showed significant effects $(P \leq 0.05)$ on most crop parameters were measured in the study. The PI $\times$ location interaction was significant for yield, 100-seed weight, seed protein, days to midbloom and maturity, plant height, and pod length (Table 4).

Average yield of PIs at St. Croix was significantly lower than at Florida (Table 4). A combination of soil factors may explain the cause of this average yield reduction at St. Croix. These include $\mathrm{P}$ fertilization of plants concomitant with nondetectable levels of soil $\mathrm{Zn}$ and $\mathrm{Fe}$ at the experimental site. Legumes are reported to have a high $\mathrm{P}$ requirement for root and plant growth and to initiate nodule formation (Ojo et al., 2007; Oseni, 2009); however, studies have shown that when both $\mathrm{P}$ and $\mathrm{Zn}$ are limiting in soil, $\mathrm{P}$ fertilizer application as done in this experiment can promote plant growth and cause dilution in tissue $\mathrm{Zn}$, which may further complicate $\mathrm{Zn}$ deficiency (Goh et al., 1995; Oseni, 2009). Iron deficiency or lime-induced chlorosis brought about by high levels of calcium and magnesium carbonates in the soil most probably was also a factor in causing lower cowpea yield at St. Croix than at Florida (Fig. 1; Tables $\mathrm{l}$ and 4). Carbonates are regarded as a major causal factor for $\mathrm{Fe}$ and $\mathrm{Zn}$ deficiency in many crop species grown in calcareous soils (Cartmill et al., 2007; De la Guardia and Alcántara, 2002; Mengel et al., 1984; Nikolic and Römheld, 1999; Valdez-Aguilar and Reed, 2010; Yang et al., 1994). Indeed, very severe leaf chlorosis was 


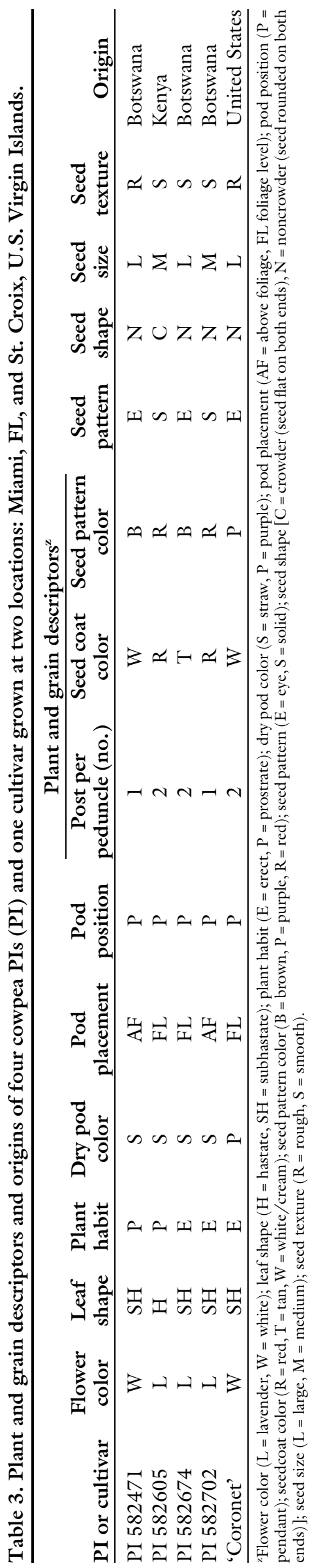

observed in plants grown at St. Croix particularly on cultivar Coronet and PI 582471 (Fig. 1). Seeds of these PIs germinated but plants grew poorly afterward and eventually died or became stunted without producing pods. Leaf chlorosis was also evident in Florida but symptoms were not as severe as in St. Croix.

PI 582605 had significantly higher yield than all other PIs in Florida $\left(1420 \mathrm{~kg} \cdot \mathrm{ha}^{-1}\right)$ but it did not differ significantly with the yield obtained by PIs 582674 and 582702 in St. Croix averaging $366 \mathrm{~kg} \cdot \mathrm{ha}^{-1}$. Although these yields are not high $\left(<1500 \mathrm{~kg} \cdot \mathrm{ha}^{-1}\right)$, they are acceptable considering the high soil $\mathrm{pH}$, along with other adverse soil characteristics (Table 1) in which these PIs were grown. These yields are also higher than those obtained by commercial cultivar Coronet and by those obtained by 26 PIs grown at St. Croix in a previous study (Goenaga et al., 2010). Cultivar Coronet and PI 582471 showed very low adaptability to alkaline soil conditions at both locations yielding significantly lower than other PIs (Table 4). In a multisite experiment seeking to identify suitable seed regeneration sites for cowpea germplasm, it was found that mean seed production at St. Croix was 40 times less than at Isabela, PR. This difference was attributed to a very high soil $\mathrm{pH}$, which limited plant growth at St. Croix (Gillaspie et al., 1999).

As an important staple in many developing areas of the world, particularly the semiarid tropics where alkaline soils are common, it is important to identify not only highyielding cowpea PIs but also those having high seed protein content. There was a significant year effect for seed protein concentration with higher average seed protein obtained in year $2(25.3 \%)$ than in year 1 $(23.3 \%)$ (data not shown). Being cowpea a heat adapted legume, it is possible that the higher temperatures and longer daylength encountered in year 2 (Table 2) because of earlier planting may have resulted in higher photosynthethic efficiency than in year 1, thus resulting in higher protein concentration. However, a similar response was not observed for yield. At both locations, PI 582702 had significantly higher seed protein concentration, averaging 28\% (Table 4).
This value is higher than that obtained for 32 cowpea PIs studied by the authors since 2008 and which had an average seed protein concentration of 24\% (Goenaga et al., 2008, $2010,2011)$. Thus, this PI may serve as a source of dietary protein particularly in the vegetarian diets of developing countries (Burstin et al., 2011).

Seed weight is an important characteristic because along with seed color it determines grain quality for commercialization (Da ConceiçãoLopes et al., 2003). The existing variation for seed weight in cowpea ranges from less than $10 \mathrm{~g}$ per 100 seeds to almost $30 \mathrm{~g}$ (Ehlers and Hall, 1997). Seed weight varied significantly among PIs and locations (Table 4). At Florida, cultivar Coronet had the highest 100 -seed weight, whereas at St. Croix, this cultivar had the lowest 100-seed weight because of poor growth at this location resulting from adverse soil characteristics. PIs 582674 and 582605 had significantly higher 100seed weight at St. Croix, averaging $13.2 \mathrm{~g}$.

Midbloom mean for all PIs was $48.6 \mathrm{~d}$ at St. Croix and $45.2 \mathrm{~d}$ at Florida (Table 4). At St. Croix, cultivar Coronet and accessions PI 582605 and 582471 took significantly longer to attain midbloom. In Florida, accession PI 582471 took significantly longer to reach midbloom and maturity. PI 582702 attained midbloom and maturity sooner than the other PIs at both locations (Table 4). At St. Croix, the accessions PI 582605, 582674, and 582702 were significantly taller than the other PIs averaging $36.3 \mathrm{~cm}$ in height, whereas in Florida, the accession PI 582605 was significantly taller $(19.3 \mathrm{~cm})$ than the rest. Plants were smaller and took longer to reach maturity at Miami probably as a response to photoperiod and cooler temperatures. Average pod length of PIs was significantly higher at Miami than at St. Croix.

In conclusion, PIs 582605 and 582674 performed relatively well despite the harsh soil environment encountered at both locations. These PIs could be used by growers or home gardeners wishing to establish a legume crop such as cowpea in areas where agricultural production may be severely restricted by high soil alkalinity of calcareous soils. 
Table 4. Average yield, weight of 100 seeds, seed protein, midbloom, maturity, plant height, and pod length of 26 cowpea PIs and one cultivar in field experiments conducted at Miami, FL (FL), and at St. Croix, U.S. Virgin Islands, (SC) in 2008 and 2009.

\begin{tabular}{|c|c|c|c|c|c|c|c|c|c|c|c|c|c|c|}
\hline & \multicolumn{2}{|c|}{$\begin{array}{c}\text { Yield } \\
\left(\mathrm{kg} \cdot \mathrm{ha}^{-1}\right)^{\mathrm{z}}\end{array}$} & \multicolumn{2}{|c|}{$\begin{array}{c}\text { 100-seed wt } \\
(\mathrm{g})^{\mathrm{z}}\end{array}$} & \multicolumn{2}{|c|}{$\begin{array}{c}\text { Seed protein } \\
(\%)\end{array}$} & \multicolumn{2}{|c|}{$\begin{array}{l}\text { Midbloom } \\
\text { (d) }\end{array}$} & \multicolumn{2}{|c|}{$\begin{array}{l}\text { Maturity } \\
\text { (d) }\end{array}$} & \multicolumn{2}{|c|}{$\begin{array}{l}\text { Plant ht } \\
(\mathrm{cm})^{\mathrm{z}}\end{array}$} & \multicolumn{2}{|c|}{$\begin{array}{l}\text { Pod length } \\
(\mathrm{cm})\end{array}$} \\
\hline & FL & SC & FL & SC & FL & $\mathrm{SC}$ & FL & SC & FL & SC & FL & SC & FL & SC \\
\hline PI 582471 & 388.8 & 132.3 & 13.8 & 7.2 & 24.9 & 23.2 & 59.3 & 49 & 97.9 & 92 & 11.9 & 15.6 & 16.4 & 7.8 \\
\hline PI 582605 & 1420.4 & 429.1 & 11 & 12.4 & 24.3 & 24 & 49 & 51.4 & 89.2 & 106.7 & 19.3 & 37.6 & 18.2 & 16.8 \\
\hline PI 582674 & 1012.7 & 435.1 & 12.3 & 14.1 & 21 & 20.8 & 39.2 & 46.8 & 74.9 & 104.6 & 15 & 35.8 & 17.3 & 14.5 \\
\hline PI 582702 & 746.8 & 234.7 & 8.8 & 9.6 & 28.1 & 27.9 & 34.4 & 44.4 & 73.5 & 104.6 & 13.2 & 35.5 & 20.1 & 18.4 \\
\hline $\operatorname{HSD}(0.05)^{y}$ & 297.3 & 206.9 & 0.6 & 3.3 & 1.4 & 3.3 & 1.5 & 4.3 & 2.1 & 2.3 & 2.3 & 6.4 & 1.4 & 2.8 \\
\hline $\mathrm{Yr}^{\mathrm{x}}$ & NS & NS & NS & $* *$ & $*$ & * & $* * *$ & NS & $* *$ & $* * *$ & NS & NS & NS & * \\
\hline PI & $* * *$ & $* * *$ & $* * *$ & $* * *$ & $* * *$ & $* * *$ & $* * *$ & $* * *$ & $* * *$ & $* * *$ & $* * *$ & $* * *$ & $* * *$ & $* * *$ \\
\hline $\mathrm{PI} \times \mathrm{Y}$ & $* * *$ & NS & NS & $* * *$ & ** & NS & $* * *$ & NS & $* * *$ & ** & $* * *$ & $* * *$ & NS & $* * *$ \\
\hline Location (L) & \multicolumn{2}{|c|}{$\star * *$} & \multicolumn{2}{|c|}{$* * *$} & \multicolumn{2}{|c|}{ NS } & \multicolumn{2}{|c|}{ ** } & \multicolumn{2}{|c|}{$* * *$} & \multicolumn{2}{|c|}{$* * *$} & \multicolumn{2}{|c|}{$* * *$} \\
\hline $\mathrm{L} \times \mathrm{PI}$ & \multicolumn{2}{|c|}{$* * *$} & \multicolumn{2}{|c|}{$* * *$} & \multicolumn{2}{|c|}{$* * *$} & \multicolumn{2}{|c|}{$* * *$} & \multicolumn{2}{|c|}{$* * *$} & \multicolumn{2}{|c|}{$* * *$} & \multicolumn{2}{|c|}{$* * *$} \\
\hline
\end{tabular}

${ }^{2} \mathrm{l} \mathrm{kg} \cdot \mathrm{ha}^{-1}=0.8922 \mathrm{lb} / \mathrm{acre}, \mathrm{l} \mathrm{g}=0.0353 \mathrm{oz}, \mathrm{l} \mathrm{cm}=0.3937$ inch.

yTukey's Studentized range test at $P=0.05$.

${ }^{\mathrm{x}} \mathrm{NS},{ }^{* *},{ }^{* *},{ }^{*}$ Nonsignificant or significant at $P \leq 0.001,0.01$, or 0.05 , respectively.
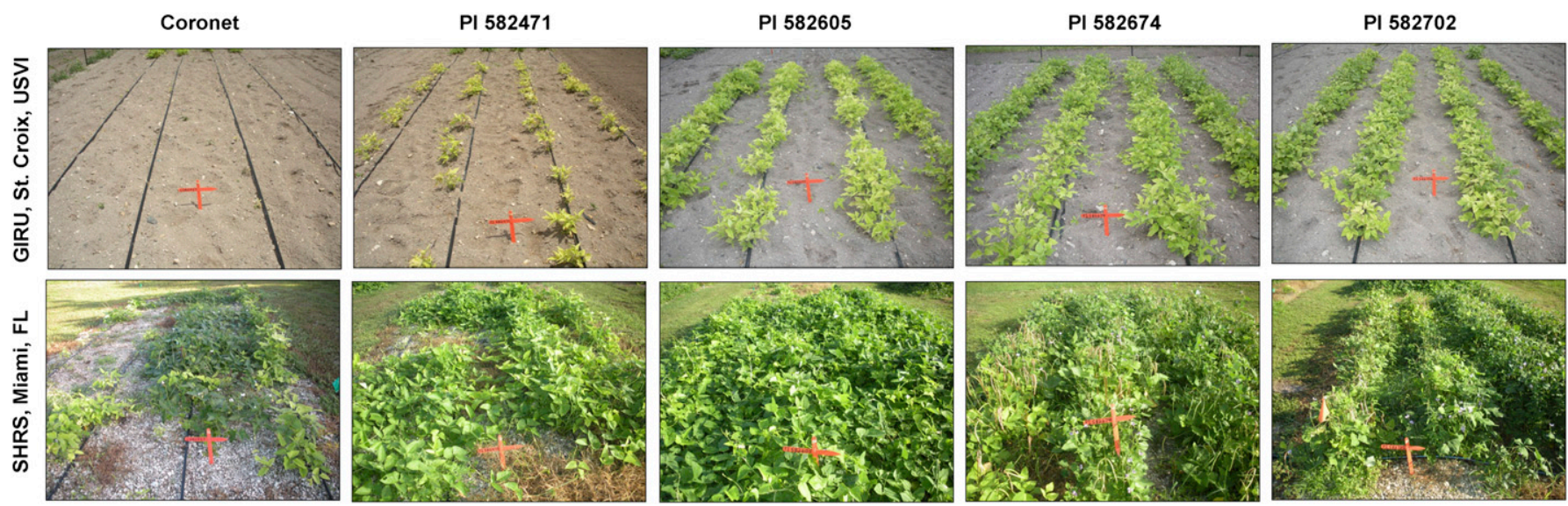

Fig. 1. Field growth of cowpea PIs planted in two alkaline soils in St. Croix, U.S. Virgin Islands, and in Miami, FL.

\section{Literature cited}

Association of Official Analytical Chemists. 2000. Official methods of analysis of AOAC International. Vol. 1: Agricultural chemicals: Contaminants; drugs, p. 29c-30c. In: W. Horwitz (ed.). AOAC official method 2001.11 protein (crude) in animal feed, forage (plant tissue), grain, and oilseeds. AOAC International, Gaithersburg, MD.

Burstin, J., K. Gallardo, R.R. Mir, R.K. Varshey, and G. Duc. 2011. Improving protein content and nutrition quality, p. 1-33. In: A. Pratap and J. Kumar (eds.). Biology and breeding of food legumes. 30 Jan. 2013. <http://oar.icrisat.org/61/ 1/ChapFood-v6_2_.pdf $>$.

Cartmill, A.D., A. Alarcón, and L.A. Valdez-Aguilar. 2007. Arbuscular mycorrhizal fungi enhance tolerance of Rosa multiflora cv. Burr to bicarbonate in irrigation water. J. Plant Nutr. 30:15171540 .
Da Conceição-Lopes, F.C., R.L. GomesFerreira, and F. Rodrigues-Freire. 2003. Genetic control of cowpea seed sizes. Scientia Agricola 60:315-318.

De la Guardia, M.D. and E. Alcántara. 2002. Bicarbonate and low iron level increase root to total plant weight ratio in olive and peach rootstock. J. Plant Nutr. 25:1021-1032.

Ehlers, J.D. and A.E. Hall. 1997. Cowpea (Vigna unguiculata) (L.) Walp). Field Crops Res. 53:187-204.

Food and Agriculture Organization of the United Nations. 2012. FAOSTAT statistics database 2010. 30 Jan. 2013. <http://faostat.fao.org/site/567/default. aspx\#ancor>.

George, E., W.J. Horst, and E. Neumann. 2012. Adaptation of plants to adverse chemical soil conditions, p. 409-472. In: P. Marschner (ed.). Marschner's mineral nutrition of higher plants. Academic Press, London, UK.
Gillaspie, A.G. Jr., R. Goenaga, S. Torres, and E. Peregrine. 1999. Identification of suitable seed regeneration sites for photoperiod-sensitive cowpea germplasm. Crop Sci. 39:1513-1515.

Goenaga, R., A.G. Gillaspie, and A. Quiles. 2008. Assessing yield potential of cowpea genotypes grown under virus pressure. HortScience 43:673-676.

Goenaga, R., A.G. Gillaspie, and A. Quiles. 2010. Field screening of cowpea genotypes for alkaline soil tolerance. HortScience 45:1639-1642.

Goenaga, R., A.G. Gillaspie, and A. Quiles. 2011. Field performance of cowpea genotypes grown under virus pressure in Puerto Rico. African Crop Sci. J. 19:97-103.

Goh, T.B., M.R. Banerjee, S. Tu, and D.L. Burton. 1995. Vesicular arbuscular mycorrhizal mediated uptake and translocation of $\mathrm{P}$ and $\mathrm{Zn}$ by wheat in a calcareous soil. Can. J. Plant Sci. 77:389-396. 
Mengel, K., M.T. Breininger, and W. Bübl. 1984. Bicarbonate, the most important factor inducing iron chlorosis in vine grapes on calcareous soil. Plant Soil $81: 333-344$.

Mulvaney, R.L. 2007. Nitrogen: Inorganic forms, p. 1123-1184. In: D.L. Sparks (ed.). Methods of soil analysis. Part 3. Chemical methods. Soil Sci. Soc. Amer., Amer. Soc. Agron., Madison, WI.

Murillo-Amador, B., E. Troyo-Diéguez, J.L. García-Hernández, R. López-Aguilar, N.Y. Ávila-Serrano, S. Zamora-Salgado, E.O. Rueda-Puente, and C. Kaya. 2006. Effect of $\mathrm{NaCl}$ salinity in the genotypic variation of cowpea (Vigna unguiculata) during early vegetative growth. Sci. Hort. 108:423-431.

Nelson, D.W. and L.E. Sommers. 2007. Total carbon, organic carbon and organic matter, p. 961-1010. In: D.L. Sparks (ed.). Methods of soil analysis. Part 3.
Chemical methods. Soil Sci. Soc. Amer., Amer. Soc. Agr., Madison, WI.

Nelson, M., W.F. Dempster, J.P. Allen, S. Silverstone, A. Alling, and M. Van Thillo. 2008. Cowpeas and pinto beans: Performance and yields of candidate space crops in the laboratory biosphere closed ecological system. Adv. Space Res. 41:748-753.

Nikolic, M. and V. Römheld. 1999. Mechanism of Fe uptake by the leaf symplast: Is Fe inactivation in leaf a cause of $\mathrm{Fe}$ deficiency chlorosis? Plant Soil 215:229-237.

Ojo, D.K., S.A. Ogunbayo, E.O. Idehen, A.F. Akinwale, and O.A. Oduwaye. 2007. Genetic evaluation of phosphorous utilization in tropical cowpea (Vigna unguiculata (L) Walp). J. Amer. Sci. 3:77-83.

Oseni, T.O. 2009. Growth and zinc uptake of sorghum and cowpea in response to phosphorous and zinc fertilization. World J. Agr. Sci. 5:670-674.

Sumner, M.E. and W.P. Miller. 2007. Cation exchange capacity and exchange coefficients, p. 1201-1230. In: D.L. Sparks (ed.). Methods of soil analysis. Part 3. Chemical methods. Soil Sci. Soc. Amer., Amer. Soc. Agr. Madison, WI.

U.S. Department of Agriculture. 1996. Soil survey laboratory methods manual. Soil Survey Investigations Rpt. No. 42, Version 3.0.

Valdez-Aguilar, L. and D.W. Reed. 2010. Growth and nutrition of young bean plants under high alkalinity as affected by mixtures of ammonium, potassium and sodium. J. Plant Nutr. 33:1472-1488.

Yang, X., V. Römheld, and M. Marschner. 1994. Effect of bicarbonate on root growth and accumulation of organic acids in $\mathrm{Zn}$-inefficient and $\mathrm{Zn}$-efficient rice cultivars (Oryza sativa L.). Plant Soil 164:1-7. 